\title{
Physico Chemical Properties and the Antinutrient status of a non-Alcoholic Beverage (Coke)
}

\author{
AKANINWOR, J O; WEGWU, M O.; *NWAICHI, E O \\ Department of Bioichemistry, University of Port Harcourt, Choba, P.M.B. 5323. Port Harcourt. Rivers State, Nigeria.
}

\begin{abstract}
The physicochemical properties and the antinutrient status of the beverage, coke were evaluated to determine its suitability for consumption and toxic levels in mammal. The mean levels of nitrates, total nitrogen, chloride, ammonia, tannin, cyanogenic glycosides and caffeine in the samples were (mg/l): $0.008 \pm 0.001,150.000 \pm$ $3.446,11.000 \pm 0.686,183.000 \pm 3.019,0.016 \pm 5.976,0.020 \pm 0.010$ and $0.146 \pm 0.002$ respectively. The $\mathrm{pH}$ of the samples gave a mean value of 3.500, while the mean metal concentrations gave (mg/l) $-0.990 \pm 0.099(\mathrm{Mg}) ; 38.030$ $\pm 0.050(\mathrm{Na}) ; 1.400 \pm 0.114(\mathrm{Fe}) ; 0.650 \pm 0.014(\mathrm{Zn}) ; 0.080 \pm 0.005(\mathrm{Mn}) ; 4.720 \pm 0.016(\mathrm{~K})$ and $10.120 \pm 0.094$ (Ca). Toxicological test using whister albino Rats, shows that the beverage was relatively safe. Generally, the results shows that the antinutrient status of the beverage fell within the standards adopted by most countries. Similarly, the other parameters fell within natural background level although few fell above WHO specifications. @ JASEM
\end{abstract}

Coca Cola is the best known commercial product in human history [Hill,1984)]. Its formula, with the zealously guarded secret ingredient $7 \mathrm{x}$, its birth as a cocaine-laden temperance drink and early days as a "brain food" and tamer of "physically exhausting terrors" "its current ingredients (stimulants, gas and corn syrup): all constitute the company's histories [Pendergrast, 1993]. Coca Cola, the brand/flavour leader of the Coca Cola company, is drunk like mother's milk in every country in the world [Metzger, 1998]. Caffeine may be responsible for human birth defects, and the Food and Drug Administration Agency has cautioned pregnant women to avoid or at least limit its consumption [Bunker and Mc Williams, 1979]. The potential toxicity of a cyanogenic glycoside depends primarily on the potential that its consumption will produce a concentration of $\mathrm{HCN}$ that is toxic to exposed animals or humans [CAC, 1991]. Flavonoids are known for their ability to strengthen capillary walls, apart from their anti-oxidant activity thus assisting circulation and helping to prevent and treat bruising, varicose veins, bleeding gums and nose-bleeds [Linda, 2003]. Phosphoric acids are used to acidify foods and beverages such as various colas, but not without controversy as to its health effects [Wikipedia, 2005]. Toxicity is an intrinsic property of chemicals by virtue of which chemicals elicit undesirable responses from living organisms, including humans, when in contact/administered [Hairston, 2001]. The aim of this work thus, is to evaluate the toxicity levels of Coca Cola beverage employing the physico-chemical properties and the antinutrient status of same beverage. The data generated for this research shall aid, in assessing the suitability of coke for consumption and NAFDAC guidelines were followed for protection of animal welfare.

\footnotetext{
* Corresponding author: Nwaichi, E O
}

\section{MATERIALS AND METHODS}

Seven samples of the beverage, Coca Cola(Coke) were collected from the production plant of Nigerian Bottling Company Plc, Port Harcourt Plant, Port Harcourt, Nigeria. Wister Albino Rats were purchased from the animal house of Biochemistry Department, University of Port Harcourt, Nigeria. Two groups of ten rats each were fed on water + feed (Control) and on Coke + feed for thirty days. Standard analytical reagent grade chemical were used for all analysis, as well as deionised water. $\mathrm{pH}$ and Temperature were determined using micro $\mathrm{pH}$ meter and micro thermometer, COD and total Nitrogen were determined using Hanna C 214 Multiparameter Bench Photometer. BOD was analysed using Hanna BOD System Oxidirect Kit while Hanna DO meter was employed for estimation of dissolved oxygen. Total dissolved solids Tester was used for TDS analysis. Nitrate, sulphate, phosphate and nitrite concentrations were determined using UV Spectrophotometer (1608 Shimadzu model) as described in [Nwaichi, 2002]. Folin Dennis method was used to determine tannin levels. Buck Scientific Atomic Absorption/Emission Spectrophotometer 200A was used to analyse the metal concentrations. Water Associates Liquid Chromatograph was used to determine the caffeine concentrations.

\section{RESULTS}

The results for the heavy metals concentration in Coca Cola is as shown in table $1 . \mathrm{Cd}, \mathrm{Pb}$ and $\mathrm{Cr}$ were not detected. Table 2 shows the results obtained for the physicochemical parameters in Coca Cola. Again, TSS, Sulphate, Nitrite and Phosphate were not detected. The concentration of some antinutrients are shown in table 3 and they are of low concentrations relatively. The $\%$ Crude protein in rat specimen is as shown in table 4 with emphasis on the carcass and the droppings. Also, the total weight gained by 
animal is indicated in table 5 while the weight of the organ is as shown in table 6 .

*Values are means \pm standard deviation for $\mathrm{n}=10$ (for tables 4, 5 and 6), $\mathrm{n}=3$ (for tables 1,2 \&3). * Means in the same row with the same superscripts are not significantly different at the 0.05 levels $(\mathrm{p} \leq$ 0.05). ${ }^{*} \mathrm{Gp} A=$ Animals fed on water + feed (Control), Gp B = Animals fed on coke + feed. $* \mathrm{BOD}=$ Biological Oxygen Demand, $\mathrm{COD}=$ Chemical Oxygen Demand, DO = Dissolved Oxygen, TDS $=$ Total Dissolved Oxygen .

Table 1: Mean Levels and Ranges (in parenthesis) of some metals in Coke

\begin{tabular}{ll}
\hline & Levels \\
Metals & \\
\hline $\mathrm{Mg}$ & $0.990^{\mathrm{c}} \pm 0.099$ \\
& $(0.880-1.120)$ \\
$\mathrm{Na}$ & $38.030^{\mathrm{b}} \pm 0.050$ \\
& $(37.990-38.100)$ \\
$\mathrm{Cd}$ & $\mathrm{ND}$ \\
$\mathrm{Pb}$ & $\mathrm{ND}$ \\
$\mathrm{Fe}$ & $1.400^{\mathrm{d}} \pm 0.114$ \\
& $(1.260-1.540)$ \\
$\mathrm{Zn}$ & $0.650^{\mathrm{a}} \pm 0.014$ \\
& $(0.640-0.670)$ \\
$\mathrm{Mn}$ & $0.080 \mathrm{~b} \pm 0.005$ \\
& $(0.075-0.086)$ \\
$\mathrm{Cr}$ & $\mathrm{ND}$ \\
$\mathrm{K}$ & $4.720^{\mathrm{c}} \pm 0.016$ \\
& $(4.700-4.740)$ \\
\hline $\mathrm{Ca}$ & $10.120^{\mathrm{c}} \pm 0.094$ \\
& $(10.000-10.230)$ \\
\hline
\end{tabular}

$\mathrm{Cd}, \mathrm{Pb}$ and $\mathrm{Cr}$ were not detected. Table 2 shows the results obtained for the physicochemical parameters in Coca Cola. Again, TSS, Sulphate, Nitrite and Phosphate were not detected. The concentrations of some antinutrients are shown in table 3.
Table 2: Mean Levels and Ranges (in parenthesis) of some Physico-chemical parameters in Coke.

\begin{tabular}{ll}
\hline Some Physico- Chemical Properties & Levels \\
\hline $\mathrm{pH}$ & $3.500^{\mathrm{a}} \pm 0.049$ \\
& $(3.440-3.560$ \\
$\mathrm{DO}$ & $0.100^{\mathrm{a}} \mathrm{a} \pm 0.014$ \\
& $(0.080-0.110)$ \\
$\mathrm{Temp}\left({ }^{\circ} \mathrm{C}\right)$ & $28.300^{\mathrm{b}} \pm 0.187$ \\
& $(28.050-28.500)$ \\
$\mathrm{TDS}(\mathrm{mg} / \mathrm{l})$ & $100.000^{\mathrm{b}} \pm 1.359$ \\
& $(98.080-101.020)$ \\
$\mathrm{COD}(\mathrm{mg} / \mathrm{l})$ & $102.000^{\mathrm{a}} \pm 0.229$ \\
& $(101.720-102.280)$ \\
$\mathrm{BOD}(\mathrm{mg} / \mathrm{l})$ & $79.600^{\mathrm{a}} \pm 0.612$ \\
& $(79.000-80.440)$ \\
$\mathrm{TSS}^{2}(\mathrm{mg} / \mathrm{l})$ & $\mathrm{ND}$ \\
$\mathrm{SO}_{4}{ }^{--}(\mathrm{mg} / \mathrm{l})$ & $\mathrm{ND}$ \\
$\mathrm{NO}_{2}{ }^{-}$ & $\mathrm{ND}$ \\
$\mathrm{NO}_{3}^{-}$ & $0.008^{\mathrm{b}} \pm 0.001$ \\
& $(0.007-0.008)$ \\
$\mathrm{TOTAL} \mathrm{NTROGEN}^{-}$ & $150.000^{\mathrm{a}} \pm 3.446$ \\
$\mathrm{NH}_{3}$ & $(145.780-54.220)$ \\
& $183.000^{\mathrm{a}} \pm 3.019$ \\
$\mathrm{PO}_{4}{ }^{2-}(\mathrm{mg} / \mathrm{l})$ & $(180.000-187.130)$ \\
\hline $\mathrm{Cl}^{-}(\mathrm{mg} / \mathrm{l})$ & $\mathrm{ND}$ \\
\hline
\end{tabular}

Table 3: Mean Levels and Ranges in $\mathrm{mg} / \mathrm{l}$ (in parenthesis) of some Antinutrients in Coke.

\begin{tabular}{llc}
\hline Tannin & $\begin{array}{l}\text { Cyanogenic } \\
\text { glycosides }\end{array}$ & Caffeine \\
\hline $0.016^{\mathrm{a}} \pm 5.976$ & $0.020^{\mathrm{b}} \pm 0.010$ & $0.146^{\mathrm{c}} \pm 0.002$ \\
$(0.009-0.023)$ & $(0.011-0.034)$ & $(0.144-0.148)$ \\
\hline
\end{tabular}

Table 4: Mean Levels and Ranges in $\mathrm{mg} / \mathrm{l}$ (in parenthesis) of $\%$ Crude Protein in Rat Specimen.

\begin{tabular}{lll}
\hline Sample & Gp A & Gp B \\
\hline Carcass & $54.731^{\mathrm{a}} \pm 5.733$ & $53.425^{\mathrm{a}} \pm 5.362$ \\
& $(43.750-62.125)$ & $(41.125-61.250)$ \\
& & \\
\hline Droppings & $23.625^{\mathrm{a}} \pm 0.054$ & $27.125^{\mathrm{a}} \pm 0.845$ \\
& $(23.575-23.700)$ & $(26.005-27.323)$ \\
\hline
\end{tabular}

Table 5: Mean levels and Ranges (in parenthesis) of Total weight gain $(\mathrm{g})$ by animal.

\begin{tabular}{lll}
\hline Sample & Gp A & Gp B \\
\hline Weight gain & $70.700^{\mathrm{a}} \pm 2.610$ & $66.200^{\mathrm{a}} \pm 18.978$ \\
& $(65.000-74.000)$ & $(27.000-100.000)$ \\
\hline
\end{tabular}

Table 6: Mean Levels and Ranges (in parenthesis) of organ weight (g) In test animals.

\begin{tabular}{lllll}
\hline $\begin{array}{l}\text { Organ } \\
\text { Weight }\end{array}$ & Liver & Kidney & Pancreas & Heart \\
\hline Gp A & $4.150^{\mathrm{a}} \pm 0.802$ & $0.570^{\mathrm{b}} \pm 0127$ & $0.460^{\mathrm{b}} \pm 0.091$ & $0.600^{\mathrm{a}} \pm 0.100$ \\
& $(3.000-5.000)$ & $(0.400-0.800)$ & $(0.300-0.600)$ & $(0.500-0.800)$ \\
\hline Gp B & $4.850^{\mathrm{a}} \pm 1.050$ & $1.190^{\mathrm{a}} \pm 0.226$ & $0.825^{\mathrm{a}} \pm 0.144$ & $0.960^{\mathrm{b}} \pm 0.102$ \\
& $(3.000-6.500)$ & $(0.900-3.000)$ & $(0.700-1.100)$ & $(0.700-1.100)$ \\
\hline
\end{tabular}

*Values are means \pm standard deviation for $\mathrm{n}=10$ (for tables $4,5 \& 6$ ), $\mathrm{n}=3$ (for tables $1,2 \& 3$ ). *Means in the same row with the same superscripts are not significantly different at the 0.05 levels $(\mathrm{p} \leq 0.05) .{ }^{*} \mathrm{Gp} \mathrm{A}=$ Animals fed on water + feed $(\mathrm{Control}), \mathrm{GpB}=\mathrm{Animals}$ fed on coke + feed. $* \mathrm{BOD}=$ Biological Oxygen Demand, $\mathrm{COD}=$ Chemical Oxygen Demand, $\mathrm{DO}=$ Dissolved Oxygen, $\mathrm{TDS}=\mathrm{Total}$ Dissolved Oxygen.

* Corresponding author: Nwaichi, E O 


\section{DISCUSSION}

The beverage sample gave $\mathrm{pH}$ values that were acidic. Owing to the fact that the phosphoric acid, formed in Coke stabilises with agitation and the evolution of Carbon iv oxide during belching, the mammal was able to tolerate this acidic $\mathrm{pH}$. The iron levels fell above the WHO limit of $1.000 \mathrm{mg} / \mathrm{l}$. Table 3 showed marked variation statistically between cyanogenic glycoside, tannin and caffeine levels in the sample and ranged between 0.009-0.148 (See table for unit). The $\%$ Crude protein in the carcass for all groups were relatively uniform throughout the study period and ranged from 35.000-62.125 mg/l. Group A gave the highest gain in weight of $70.700 \mathrm{~g}$. There were no significant differences among the three rat groups as per the liver. High total

nitrogen concentration could be attributed to the additives used. The solubility of both the ferric and ferrous iron can be enhanced by the presence of inorganic and organic complex forming ions in the natural water system, thus increased iron availability. $\mathrm{Zn}$ levels fell within normal range. Qualitative analysis gave low acceptable levels of cyanogenic glycosides $(0.020 \mathrm{mg} / \mathrm{l})$, tannins $(0.016 \mathrm{mg} / \mathrm{l})$ and Caffeine $(0.14$. mg/l). The $\%$ Crude protein ranged as follows: Gp A > Gp B (See table 4) for the carcass and the reverse: $\mathrm{Gp} B>\mathrm{Gp} A$ for the faecal droppings. The low biological value of plant proteins is attributable to incomplete digestion of plant proteins thus making most of the amino acids unavailable for absorption [Novak and Haslberger, 2000]. This is the possible reason why crude protein trend reversed in the faecal samples. There was recorded no negative weight balance (loss in body weight). Feed conversion ratio (FCR) was highest in rats group A (0.091) followed by rats group B (0.079). There was no significant difference in the relative organ weight between the two groups. This shows that the test samples did not contain enough anti nutritional factors that could affect the utilization of the samples negatively and thus affect the utilization of the beverage negatively and thus affect the Kidney and Pancreas. Quantitative analysis of Coke indicated presence of alkaloids and .flavonoids. The study has shown that our case study beverage is a fair one having acceptable values in most of the traditional parameters monitored.

Acknowledgement: The authors are grateful to Dr. Silva of Central Research Laboratory - CMUL,
Lagos; Mr. Japhet of Central Research Laboratory, University Of Port Harcourt and Mr. Emeka of Quality Assurance Laboratory of Nigerian Bottling Company, Port Harcourt Plant for their contributions during the analyses. The funding for this work was done by the researchers.

\section{REFERENCES}

Hill, D. (1984).Price Guide to Coca-cola collectibles (P. A. Radnor, ed), pp 7-11. Wallace-Homestead Press, New York.

Pendergrast, M. (1993).For God, Country and CocaCola NY: Scribners), pp 20-37. New York.

Metzger, T. (1998). Who put the coke in Coca Cola? (Garden City, NY: Doubleday), pp 1-12. New York.

Bunker, B. and McWilliams, J. (1979). National Soft Drink association, Diet. J. Am. 74: pp28-32.

CAC. (1991). Codex Alimentarius, Codex Standard for Edible Cassava Flour (African Regional Standard). Food and Agriculture Organization of the United Nations (CODEX STAN), p176.Vol. X Suppl 4. Rome.

Linda, L.(2003). Nutritional Health Bible.www. healthdiets. net/healthsearch/flavone.html. 15/3/2005. p1.

Wikipedia, the free encyclopedia. (2005). www.wikipedia.org/wiki/phosphoricacid. 6/1/2005. pp1-17.

Hairston, D. (2001).Wastewater Treatment - Oxygen to the rescue: Chem., Eng: Jan/2001, pp 35-37.

Nwaichi, E. O. (2002). Compendium of Chemical Analytical Methods commonly used in the Central Research Laboratory, Afaide Publishers, pp 9-33.

Novak, W.K. and Haslberger, A.G.(2000). Substantial equivalence of antinutrients and Plant toxins in Genetically modified foods. Food and Chem. Toxicology, p 38. 